\section{Lacking health insurance, U.S. Hispanics face higher health risks ${ }^{1}$}

Based on: American College of Physicians-American Society of Internal Medicine. No health insurance? It's enough to make you sick. Latino community at great risk [Internet site]. Philadelphia, Pennsylvania, United States of America: ACP-ASIM; 2000. Available from: http://www.acponline.org/uninsured. Accessed 24 March 2000.
Primarily because so many of them do not have health insurance, persons of Latin American descent in the United States of America suffer significantly worse health outcomes than do other groups in the country, according to a study released recently by the American College of PhysiciansAmerican Society of Internal Medicine (ACPASIM).

ACP-ASIM is the largest medical specialty organization in the United States and also the second largest physician group in the country. Members include more than 115000 internal medicine physicians and medical students. Internists are the major providers of medical care to adults in the United States.

The health care system in the United States relies heavily on payments made through private health insurance (1). Consumer demand for such insurance began to grow in the 1920s. By the 1940s it had become prevalent, and employment-based private insurance continued to expand through the 1970s (2).

Since 1980, however, the percentage of persons in the United States under age 65 with private health insurance, either purchased individually or obtained through the workplace, has declined. Faced with mounting health-insurance costs, many companies increased their employees' copayments for medical services, raised the amounts individuals had to pay before receiving insurance benefits, and limited the insurance coverage in a variety of ways. These changes shifted a larger share of health expenses to workers, many of whom either lost or declined job-based health insurance (2).

The number of Americans without healthinsurance coverage rose from $11.8 \%$ in 1980 to $16.3 \%$ in 1998. Between 1990 and 1995, the percentage of nonelderly Americans who received heath insurance through an employer dropped from $67 \%$ to $64 \%(2)$.

Given the heavy reliance on private health insurance in the United States, persons without such protection have less access to regular medical care, face delays in getting necessary diagnoses and treatment, experience poorer outcomes when ill, endure greater suffering, and have a higher level of premature death. This situation endangers the health and lives of all persons, adds cost to the 
health care system, and reduces worker productivity (2).

The medical treatment provided to the uninsured is often more expensive than the preventive, acute, and chronic care that insured persons receive, in part because the uninsured are more likely to receive medical care in a hospital emergency department than in a physician's office. These higher costs are passed on to insured persons through cost shifting and higher health insurance premiums, and they also result in higher taxes to finance public hospitals and public insurance programs (2).

\section{UNINSURED LATINOS}

More than a third of the Hispanics in the United States do not have health insurance. And while Latinos make up only $11.7 \%$ of the country's population, they represent more than $25 \%$ of the uninsured population in the country, points out the new ACP-ASIM study, which drew on nearly 100 other articles, studies, and reports done over the past decade.

Compounding the seriousness of the problem is the rapid growth in the number of Latinos in the United States. The Hispanic population is rising faster than average for the country, and Latinos are expected to become the largest minority group in the United States by the year 2005.

The Latino population in the United States is diverse. Persons of Mexican origin make up the largest subgroup. They comprise just over $65 \%$ of the country's Hispanic population and live primarily in the Southwest of the United States.

The next two largest Hispanic subgroups residing in the continental United States are Puerto Ricans and Cuban-Americans, making up 9.6\% and $4.3 \%$ of the Latino population, respectively. These two subgroups live primarily in the northeastern states of New York and New Jersey and in the southeastern state of Florida.

Of the remaining Hispanics in the United States, $14.3 \%$ of them are of Central and South American origin, and $6.6 \%$ come from elsewhere, including the Dominican Republic.

While Latinos live in every state of the United States, just under seven out of every ten live in just four states: California, Texas, Florida, and New York.

Latinos living in the Southwest and the South are more likely to be uninsured than Hispanics living in other parts of the United States. In both Texas and California, some $40 \%$ of Latinos lack health insurance. Among the various subgroups, persons of Central and South American origin are the most likely to be uninsured, followed by MexicanAmericans. Puerto Ricans are the most likely to have insurance, either through private programs or through Medicare or Medicaid, which are two national publicly funded government health programs covering, respectively, persons over age 65 and the poor, blind, and disabled.

Many Latinos lack health insurance because they work in lower-skilled and lower-paid sectors of the economy, which are less likely to provide insurance as a benefit. While $85 \%$ of non-Hispanic white workers in the United States have employment-based insurance, that is true for only $60 \%$ of Latino workers.

As with other persons in the United States without health insurance, uninsured Latinos experience reduced access to health services in numerous forms. They are less likely to have a regular source of care, to have visited a physician in the last year, to have received a routine physical examination, and to rate their own health as excellent or very good. Taken together, those factors mean Hispanics are less likely to receive timely and appropriate preventive and ambulatory care and thus more likely to need more intensive, more expensive services later. Lacking a regular relationship with a physician, Hispanics are more likely than nonHispanic whites to use a hospital clinic or outpatient department as their usual source of care.

Vaccination levels are also lower than average among some segments of the Latino population in the United States. At the age of 2 years, Hispanic children are a third less likely to be fully vaccinated against childhood diseases than are non-Hispanic white children. Data from 1996 showed that among adults over age 65, Latinos were a third less likely than non-Hispanic whites to be vaccinated for influenza.

A lack of health insurance is also related to inadequate screening and late diagnosis of many illnesses. A 1994 study of cancer patients in Florida found that uninsured Hispanic males were nearly four times as likely to be diagnosed with prostate cancer at a later stage. Those same researchers found that uninsured Hispanic women had more than twice the likelihood of having their breast cancer detected at a later stage. Comparing insured and uninsured Latino women using data from national health surveys done in 1990 and 1992, it was found that the uninsured women were only a third as likely as the insured ones to have had a mammogram and only two-thirds as likely to have had a Pap smear. 
Latinos in the United States experience a higher-than-average prevalence of chronic and infectious diseases, including diabetes, hypertension, and tuberculosis. Latinos are nearly twice as likely to have diabetes as the rest of the population. And while diabetes is the seventh leading cause of death in the United States, it is the fourth leading cause among Hispanics. Among Latinos, diabetes tends to strike younger persons and to lead to complications that in part may be due to difficulties in obtaining adequate health care. Regardless of their income level, Mexican-Americans with hypertension are less likely to receive appropriate medication than is the general population. Hispanics are twice as likely to have tuberculosis as the total population of the United States.

This new study is the second in a series of reports the ACP-ASIM is releasing on the lack of health insurance in the United States. The first paper in the series, which examined the overall health consequences for uninsured Americans, was published in November 1999 (2). The third paper in the series will deal with the special health problems of uninsured women.

\section{SINOPSIS}

\section{La falta de seguro de salud hace que los hispanos de Estados Unidos corran mayores riesgos sanitarios}

Según un estudio publicado recientemente por el American College of Physicians-American Society of Internal Medicine (ACP-ASIM), una de las principales organizaciones de especialistas médicos de los Estados Unidos de América, los individuos de ascendencia latinoamericana de este país tienen peores desenlaces de salud que otros grupos étnicos, en gran medida debido al hecho de que son muchos los que carecen de seguro de salud. Aunque los latinoamericanos solo representan $11,7 \%$ de la población del país, constituyen más de 25\% de la población de los Estados Unidos sin seguro de salud. Como otras personas de este país sin seguro de salud, los latinoamericanos no asegurados tienen menos probabilidades de acceder a una fuente regular de atención sanitaria, de haber consultado con un médico en el último año, de haberse sometido a un examen médico de rutina, de calificar su propia salud como excelente o muy buena y de recibir atención ambulatoria y preventiva en el momento adecuado, lo cual aumenta la probabilidad de que posteriormente necesiten servicios más intensivos y caros. Debido a la ausencia de una relación regular con un médico, los hispanos son más propensos que los blancos no hispanos a utilizar las consultas externas o el servicio de pacientes ambulatorios de un hospital como fuente habitual de atención de salud.

\section{REFERENCES}

1. Pan American Health Organization. United States of America. In: Volume II: Health in the Americas, 1998 edition. Washington, D.C.: PAHO; 1998. p. 507518. (Scientific Publication 569).
2. American College of Physicians-American Society of Internal Medicine. No health insurance? It's enough to make you sick-scientific research linking the lack of health coverage to poor health
[Internet site]. Philadelphia, Pennsylvania, United States of America: ACPASIM; 1999. Available from: http://www. acponline.org/uninsured. Accessed 24 March 2000. 